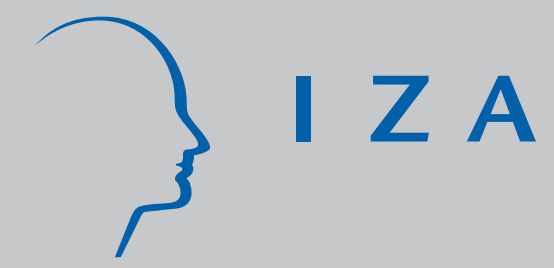

IZA DP No. 220

The Changing Profile of Mexican Migrants to the United States: New Evidence from California and Mexico

Wayne A. Cornelius

Enrico A. Marcelli

November 2000 


\title{
The Changing Profile of Mexican Migrants to the United States: New Evidence from California and Mexico
}

\author{
Wayne A. Cornelius \\ University of California, San Diego and IZA, Bonn
}

Enrico A. Marcelli

University of Massachusetts, Boston

Discussion Paper No. 220

December 2000

\author{
IZA \\ P.O. Box 7240 \\ D-53072 Bonn \\ Germany \\ Tel.: +49-228-3894-0 \\ Fax: +49-228-3894-210 \\ Email: iza@iza.org
}

This Discussion Paper is issued within the framework of IZA's research area Mobility and Flexibility of Labor Markets. Any opinions expressed here are those of the author(s) and not those of the institute. Research disseminated by IZA may include views on policy, but the institute itself takes no institutional policy positions.

The Institute for the Study of Labor (IZA) in Bonn is a local and virtual international research center and a place of communication between science, politics and business. IZA is an independent, nonprofit limited liability company (Gesellschaft mit beschränkter Haftung) supported by the Deutsche Post AG. The center is associated with the University of Bonn and offers a stimulating research environment through its research networks, research support, and visitors and doctoral programs. IZA engages in (i) original and internationally competitive research in all fields of labor economics, (ii) development of policy concepts, and (iii) dissemination of research results and concepts to the interested public. The current research program deals with (1) mobility and flexibility of labor markets, (2) internationalization of labor markets and European integration, (3) the welfare state and labor markets, (4) labor markets in transition, (5) the future of work, (6) project evaluation and (7) general labor economics.

IZA Discussion Papers often represent preliminary work and are circulated to encourage discussion. Citation of such a paper should account for its provisional character. 
IZA Discussion Paper No. 220

December 2000

\title{
ABSTRACT \\ The Changing Profile of Mexican Migrants to the United States: New Evidence from California and Mexico*
}

\begin{abstract}
Using recent data from southern California and Mexico we challenge the notion that the demographic profile of post-1970 Mexican migrants to the United States has remained constant. We find that more recent cohorts of migrants: (1) are more likely to settle permanently in the United States, (2) have higher proportions of females, (3) are younger, (4) have higher educational attainment, (5) are increasingly likely to originate in southern Mexico and the Mexico City Metropolitan area, and (6) are increasingly likely to depart from urban areas within Mexico. Although we find no direct evidence that the legalization programs mandated by the Immigration Reform and Control Act of 1986 led to a stronger propensity to settle permanently in the United States, logistic regression analyses demonstrate the importance of the other three principal explanatory factors suggested by Cornelius (1992), namely, economic crisis in Mexico, the changing character of U.S. demand for labor, and social networks.
\end{abstract}

JEL Classification: J61, F22

Keywords: Immigration, Mexico, United States, Undocumented, Gender, Region, Settlement

Wayne A. Cornelius

Center for Comparative Immigration Studies

University of California -San Diego

La Jolla, CA 92093-0510

Tel: $+1(619) 534-7852$

Fax: +1 (619) 534-6447

Email:wcorneli@ucsd.edu

\footnotetext{
* The authors gratefully acknowledge grants from the James Irvine Foundation, the John Randolph and Dora Haynes Foundation, and the U.S.-Mexico Science Foundation. The field research in Los Angeles County was jointly undertaken by the University of Southern California and El Colegio de la Frontera Norte. We are also indebted to Craig R. Cornelius and Rafael Vergara for research assistance. Very useful comments on an initial draft were provided by Manuel García y Griego, David Heer, and Pascale Joassart. We also have benefited from conversations with Paul Ong, Robert Mare, Shannon McConville, Manuel Pastor, Jr., and Rafael Alarcón, as well as from suggestions provided by three anonymous reviewers. We bear full responsibility for all interpretations and conclusions in this paper.
} 
Reviewing the evidence concerning the characteristics of Mexican migrants to the United States, Cornelius (1992) synthesized data gathered by himself and 67 other U.S. and Mexican researchers during the 1970s and 1980s, using a wide range of research methodologies and sites. Four trends were identified in the data: (1) permanent settlement of Mexican migrants to the United States began to increase in the 1970s and accelerated during the 1980s; (2) the flow of Mexican migrants became more diverse geographically, originating increasingly in nontraditional sending states and large cities, including the Mexico City metropolitan area; (3) the skill composition of the Mexican migrant flow began to improve; and (4) the gender composition of Mexican migration shifted, becoming less male-dominated, as more single women and whole families began to migrate. ${ }^{1}$

Cornelius (1992) hypothesized that these changes in the profile of Mexico-to-U.S. migrants could be explained by: (1) the changing composition of U.S. demand for migrant labor, with non-agricultural, year-round employment opportunities increasing relative to short-term agricultural jobs; (2) the economic crisis in Mexico during the 1980s, which forced Mexicans in nontraditional source areas to enter the U.S.-bound migratory flow; (3) changes in U.S. immigration law, especially the legalization provisions of the 1986 Immigration and Control Act (IRCA), which increased family reunification migration by women and dependent children; and (4) the maturing of transnational migrant networks, which both altered the demographic composition of migration flows and strengthened incentives for permanent settlement in the United States. Bean, Espenshade, White, and Domowski (1990: 114) agree especially with Cornelius' (1992) third hypothesis regarding undocumented Mexican immigrants, noting that employer sanctions (one of IRCA's three main provisions) were more likely to discourage potential adult Mexican male migrants, who were more likely than their female and minor counterparts to migrate in the search of work.

Durand (1998), using an "ethnosurvey" technique to investigate the characteristics of those migrating between Ameca, Jalisco and the United States over the past three decades, also confirms several of Cornelius's (1992) generalizations. But a recent co-authored paper by the same author (Durand, Massey, and Zenteno 2001) and published by this journal directly challenges them, arguing instead that Mexican migration to the United States: (1) has become more cyclical (i.e., short-term); (2) continues to originate primarily in west-central Mexico (and its increasing "urban-ness" simply reflects the overall urbanization of the Mexican population); 
(3) has become less selective in terms of educational attainment; ${ }^{2}$ and (4) remains dominated by working-age males. Using data from both Mexico and the United States, Durand, Massey, and Zenteno (2001: 124) characterize Mexican migration to the United States as an example of "remarkable continuity" over time. ${ }^{3}$

The purpose of this paper is to test this latest hypothesis of high continuity in the profile of Mexican migrants entering the United States by examining recent data from southern California and Mexico. Specifically, we analyze post-1970 trends in gender composition, the ratio of sojourners to permanent settlers, age composition, educational attainment, regional origins, and the urban-rural composition of source regions. We also examine factors influencing recent increases in the incidence of permanent settlement among Mexican migrants.

Although no specific theoretical framework is outlined by Durand, Massey, and Zenteno (2001), the continuity hypothesis falls most appropriately under the theory of cumulative causation (Myrdal 1957). This is because each act of migration is said to alter the social context in which migration decisions are made such that future migratory movement is more likely regardless of whether conditions initiating migration remain over time (Massey 1990; Massey, Arango, Hugo, Kouaouci, Pellegrino, and Taylor 1999: 45-46). In short, more of the same can be expected. Although Cornelius (1992) also fails to offer an explicit theory of Mexican migration to the United States, his analysis generally conforms to what has come to be known as a migration systems approach (Mabogunje 1970; Portes and Borocz 1989; Kritz, Lim, and Zlotnick 1992). While not denying the influence of cumulative causation, this approach places more explanatory weight on economic and political activity in labor-importing countries. Put simply, firms seeking to lower labor costs and to increase investment returns can be expected to petition government to implement domestic and foreign policies favorable to business interests and likely to create or reinforce international migration flows (Castles and Miller 1998; Rosenblum 2000; Sassen 1988). Immigration controls fail, in the final analysis, because the demand for immigrant labor has become structurally embedded in the political economies of receiving countries (Cornelius 1998b). 


\section{DATA AND METHODS}

The primary data used in this paper come from four sample surveys carried out in southern California during the 1994-1996 period: the 1994 University of Southern California and El Colegio de la Frontera Norte (USC-COLEF) Household and Mobile Population Surveys conducted in Los Angeles County; and the 1996 University of California-San Diego (UCSD) surveys of immigrant-dependent firms and their immigrant employees, and of irregularly employed migrant workers (comparable to the USC-COLEF Mobile Population Survey), conducted in San Diego County. Supplementing these data is information obtained from the 1980 and 1990 U.S. Censuses and from two surveys conducted in Mexico: the 1979 Mexican National Household Survey for Emigration (ENEFNEU) and the 1992 Mexican National Survey on Demographic Dynamics (ENADID).

The 1994 USC-COLEF Household Survey is a probability sample of census tracts in Los Angeles County in which, according to the 1990 Census, 25 percent or more of the total population was born in Mexico. The survey asked adults from 271 Los Angeles County households, in which at least one person was born in Mexico, a series of questions that produced detailed demographic, migration, legal status, and economic information for 661 persons. A more detailed description of the survey is offered in Marcelli and Heer (1998). The 1994 USC-COLEF Mobile Population Survey provides valuable information concerning 670 foreign-born Mexicans who were interviewed at day-labor sites, commercial centers, lunch trucks, and soccer fields throughout Los Angeles County. While certain members in the USC-COLEF Household Survey may be sojourners, those found in the Mobile Population Survey are less likely to be settlers than persons interviewed in the Household Survey.

The 1996 UCSD survey builds on two previous surveys of immigrant-using firms and their employees in California, conducted in 1983-84 and 1987-88 by the Center for U.S.-Mexican Studies. Given the impossibility of sampling the entire universe of Mexican immigrantdependent firms in California, these earlier surveys employed an eclectic set of sampling techniques using information obtained from INS raid lists, industry and telephone-directory lists, labor-union officials, and other sources (Cornelius 1992: 190-195). Twenty percent of the 112 firms represented in the 1996 UCSD survey were drawn from the samples for the 1983-84 and 1987-88 surveys; employers in all firms participating in these earlier surveys that were still in business and operating in San Diego County in 1996 were re-interviewed. The remaining 80 percent of 1996 sample firms were selected randomly from complete lists of businesses, compiled by a market research firm, operating in the ten sectors of the San Diego County 
economy that are most heavily dependent on immigrant labor: agriculture and horticulture, hightech manufacturing, low-tech manufacturing (except clothing), apparel, food processing, construction, hotels and motels, restaurants, landscape and building maintenance, and miscellaneous services (dry cleaners, car washes, laundries, convalescent homes). Firms selected for possible study were contacted by telephone to determine the proportion of foreign-born employees in their production work force. Only those firms reporting that at least 50 percent of their production workers were immigrants were included in the final sample. Interviews with 501 immigrant workers employed in these firms were distributed evenly across the ten economic sectors listed above; five or six randomly chosen immigrant employees per firm were interviewed, away from the work place. In addition, 116 "street-corner" workers - foreign-born persons who seek day-labor in construction, landscaping and other occupations by standing near public thoroughfares and shopping mall entrances - were interviewed. These irregularly employed workers were randomly selected from persons who gathered at four different streetcorner labor markets dispersed throughout San Diego County, during the first half of 1996.

For the present analysis, we pool the regularly employed and irregularly-employed migrant workers of Mexican nationality (79 percent of the total sample) in the 1996 UCSD surveys, and compare their demographic and socioeconomic characteristics with those of Mexican migrants interviewed in the 1994 USC-COLEF surveys to identify recent changes in the Mexican migrant profile. ${ }^{4}$

Finally, using data from the 1996 UCSD surveys, we identify factors likely to influence the intention of Mexican migrants to remain in the United States permanently. Specifically, we use logistic regression analysis to estimate how well (1) certain demographic variables (sex, age, years of schooling, etc.), (2) the historical economic context of migration (i.e., whether one migrated to the United States during the Mexican economic crisis of 1982-1988), (3) the opportunity to legalize one's status in the U.S. under IRCA's "amnesty" provisions, (4) the availability of year-round employment in the United States, and (5) membership in social networks that include friends born in the United States help explain variation in respondents' intentions to settle in the United States. All independent variables are defined in Table 1.

\section{$<$ TABLE 1 ABOUT HERE $>>$}

The model employed in this paper is shown below. While we first regressed one's intention to reside permanently in the United States (Settle) on demographic variables only, we 
proceeded in subsequent runs to include proxies for economic push factors, immigration policy, the U.S. demand for labor, and social networks. The final model includes all variables shown in Table 1, listed under the five explanatory categories.

Settle $=f($ Demographic Characteristics, Economic Crisis, Immigration Policy, U.S. Labor Demand, Social Networks) 


\section{RESULTS}

\section{Gender Composition}

Durand, Massey, and Zenteno (2001) pooled data from the 1990 U.S. census one-percent Public Use Microdata Sample (PUMS) and ENADID in an effort to (1) adjust for differences in selection probabilities between the two data sources, and (2) simulate what the data on the U.S. side of the border would look like if persons on both sides of the border were asked the same questions. Specifically, they standardized the Mexican foreign-born population enumerated in the 1990 PUMS by age composition for all persons, and by year of departure for those aged 12 and over to control for the selective process of settlement. ${ }^{5}$ When using ENADID data only, Durand, Massey, and Zenteno (2001) find that Mexico-U.S. migration continues to be highly selective of males. In fact, the proportion of males appears to be rising. While 77.3 percent of all Mexican migrants who departed between 1970 and 1974 were male, 82.3 percent of those who left between 1985 and 1989 were, and 87.4 percent were among those who departed between 1990 and 1992. When using the pooled 1990 PUMS and 1992 ENADID data, and controlling for selective U.S. settlement, males do not appear to be as dominant, but the increase in their representation has been slightly higher - from 58 percent for those who departed in the early 1970s to 68 percent among those who departed between 1985 and 1989. In short, whether one looks at Mexican migration data from Mexico or the United States, it appears that males continue to dominate the flow.

Using more recent data from San Diego and Los Angeles Counties (Table 2) and comparing the 1970-74 and 1990-92 Mexico departure (or U.S. entry) cohorts, we find strong evidence of gender proportion convergence -- not the slight divergence interpreted as continuity by Durand, Massey and Zenteno (2001). In fact, among foreign-born Mexicans headed for Los Angeles County in the early 1990s, females appeared to have outnumbered males.

\section{$<$ TABLE 2 ABOUT HERE $>>$}

While 75 percent of those foreign-born Mexican migrants residing in San Diego County in 1996 who arrived between 1970 and 1974 were male, only 56.5 percent were among those who arrived between 1990 and 1992. Similarly, 53.1 percent of those foreign-born Mexicans residing in Los Angeles County in 1994 who arrived as part of the 1970-74 entry cohort were male, and despite a quick rise in the male proportion between 1975 and 1984 to 59.3 percent, the 
proportion was virtually unchanged at 53.5 percent for the 1985-89 cohort. However, after 1989 the proportion of males begins to decline and females actually become the majority (56.2 percent) in the 1990-92 entry cohort. These results suggest a gradual feminization of the Mexican migrant flow, commencing in the early 1970s and accelerating sharply in the 1990s. A similar surge in female Mexican migration in the 1990s has been found in both large and small cities in Georgia, with women outnumbering men in the most recent (1993-98) cohort (Rees, Miller, and Arillo 1998; Herández-León and Zúñiga 2000: 60). Ethnographic evidence suggests that Mexican women migrating to the United States since 1990 is strongly mediated by kinship networks. Young single women often are encouraged to migrate by their older siblings to care for young children and do housework in households where both the father and mother are employed outside the home; married women typically migrate to reunite with their husbands; older women come to care for their grandchildren (Hirsch 1998; Malkin 1999).

\section{Settlement Patterns}

The feminization of the Mexican migration flow is strongly related to the trend toward more permanent settlement in the United States. The latter trend is illustrated by our 1996 data from San Diego County: While 70.0 percent of the Mexican workers who entered in the early 1970s identified the United States as their principal country of residence, 87.1 percent did among the 1985-89 cohort (Table 3).

\section{$<<$ TABLE 3 ABOUT HERE $>>$}

It might be argued that data from major urban regions of southern California, with their well-consolidated Mexican migrant networks and satellite communities of emigrants (Waldinger 1997; Cornelius 1998b), are more likely to capture the settler population, especially females, and tend to miss those who continue to engage in short-term, shuttle migration. And with females being more likely than males to remain permanently in the U.S, the above results could be doubly settler-biased. But data gathered south of the border, as well as pooled age-standardized U.S. and Mexican data, may be sojourner-biased. For example, the male percentage reported using the ENADID or the Mexican Migration Project data in both the 1970-74 and the 1985-89 entry cohorts is substantially higher than in the standardized 1990 PUMS data. This is consistent with the common notion that males are more likely to move back and forth across the border. Interestingly, however, although the male proportion of the two departure cohorts remains high 
(76.8 and 74.8 percent, respectively) according to the Mexican Migration Project data, the proportion has actually been declining since the early 1980s (Durand, Massey, and Zenteno 2001: 121).

A more robust method of determining whether the settler-sojourner composition of the Mexico-to-U.S. migrant population has changed or remained constant over time is to estimate the relative growth of the sojourner and settler populations. This can be done in two ways. First, one can assume that women and children are less internationally mobile than men, and divide the number of women and children by the number of men over time to obtain a settler ratio. Hondagneu-Sotelo (1994: 199), for instance, argues that migration from Mexico to the United States transforms gender relations within households, and immigrant women "advance settlement along three structural dimensions . . . the construction of community-wide social ties; employment in relatively stable, year-round jobs; and the utilization of private and public institutional forms of assistance, including credit." In short, as men migrate women "strengthen their own position in the family, further deepening their commitment to settlement" (HondagneuSotelo 1994: xxiv; see also Hondagneu-Sotelo 1997). Chávez (1988) further contends that because female Mexican migrants tend to be married and with children (many of whom were born in the United States), they are more likely to become permanent settlers. Alarcón (1995a, b) supports such claims and suggests that both U.S. and Mexican governments policies helped create well-developed social networks that led to increased settlement.

Second, using representative national data from Mexico to compute the sojourner numerator and from the U.S. for the settler denominator, we can estimate a sojourner ratio. If the settler ratio has risen or the sojourner ratio has fallen over time then it is more likely that Mexican migrants have been settling more over time. A proxy for the settler ratio may be deduced from Tables 2 and 3, which show that the proportion of females among the Mexican migrant population and the percent identifying the U.S. as their principle country of residence have been rising. The method employed here to produce a sojourner ratio uses the Mexican Labor Ministry's ENEFNEU sample as a proxy for sojourners and the adjusted foreign-born Mexican population residing in the United States in 1980 (Warren and Passel 1987) as a proxy for settlers. ${ }^{6}$ There were 519,000 "absent workers" reported by household members who were interviewed and 471,000 "returned workers" who were directly interviewed in 1979 in the ENEFNEU survey (García y Griego 1983). Dividing these 990,000 Mexican migrants by the 2,326,000 foreign-born Mexicans estimated to have been permanently residing in the U.S. (according to the 1980 census) yields an estimated sojourner ratio of 43.6 percent. Using the 
1,220,075 Mexican migrants reported to have returned to Mexico between 1988 and 1992 in the 1992 ENADID data (Bean, Corona, Tuirán and Woodrow-Lafield 1998: 63) as a proxy for sojourners and the 4,298,000 foreign-born Mexicans enumerated in the 1990 PUMS as a proxy for settlers, we find that the estimated proportion of sojourners has fallen to 28.4 percent. In other words, Mexican migrants appear to be settling in the United States more often, even when we look at data from both sides of the border -- a result that corroborates our findings from southern California.

A 1997 survey of Mexican immigrants in Texas who had filed naturalization applications with the INS yields further evidence of a settlement pattern that apparently is not limited to southern California. When asked about their motivations for seeking naturalization, 83.9 percent of the respondents said that they planned to reside in the United States for the rest of their lives (Freeman, González-Baker, Orozco, and Plascencia 1999).

\section{Age Composition}

Durand, Massey, and Zenteno (2001) report, using ENADID data, that although the age distribution of the Mexican migrant population becomes progressively younger from earlier to later departure cohorts as measured by "age at survey," it changes very little when measured by "age at departure." One would expect this to be the case; migrants who left in the early 1970s, for instance, have aged and it is less likely to find younger persons among their cohort in 1992 than among those who left in the subsequent two decades. It is also consistent with the notion that people are more likely to migrate before or during their economically productive years than afterwards. Thus, it is more likely to find a "greening" effect using the "age at survey" rather than the "age at departure" variable.

\section{$<$ TABLE 4 ABOUT HERE $>>$}

Using data (specifically, the age-at-departure variable) from the 1994 USC-COLEF and 1996 UCSD surveys, we find, contrary to the "high-continuity" hypothesis, that there is significant fluctuation in cohort age composition (Table 4). For example, while the share of those aged 12 to 18 years fell from 13.8 percent (1970-74 cohort) to 8.9 percent (1990-92 cohort) according to ENADID data ${ }^{7}$, this group's proportional representation rose from 15.2 to 39.0 percent in the USC-COLEF household survey. However, in San Diego County, the 12 to 18 -yearold group declined slightly from 23.5 to 21.4 percent according to the 1996 UCSD survey, and 
the proportion fell among the Los Angeles County sojourner population (i.e., those interviewed in the USC-COLEF Mobile Population Survey), from 24.0 to 22.6 percent. Although not shown in Table 4, extending the analysis to those who arrived after 1992, our data reveal an even larger drop, to 15.8 percent, in the Los Angeles County household (mobile population) survey, and to 6.5 percent in the UCSD survey.

Compared to the small rise in the proportion aged 19 to 34 in the ENADID data from the 1970-74 to the 1990-92 cohort, this group's proportional representation among Mexican migrants workers in San Diego appears to have risen moderately, but to have fallen slightly or remained constant in Los Angeles County. In sum, there appears to be little evidence of continuity in the age profile of successive Mexican migrant entry cohorts during the two decades beginning in the early 1970s.

\section{Educational Attainment}

A number of studies have noted the declining average educational attainment of Mexican migrants relative to members of other ethno-racial groups in recent decades (Borjas 1997; Durand, Massey and Zenteno 2001). While some researchers note that newer Mexican migrants have higher levels of educational attainment than earlier entry cohorts (Myers 1998: 162, 176178), Durand, Massey, and Zenteno (2001) question this assertion. They suggest that despite rising educational levels in Mexico, and after controlling for age composition and settlement selectivity, the Mexican migrant flow is becoming less selective in terms of educational attainment. Once again they show this using both Mexican and standardized U.S. data. ${ }^{8}$

\section{$<$ TABLE 5 ABOUT HERE $>>$}

In contrast, our data from California show that the Mexican migrant flow, regardless of the ratio of settlers to sojourners, has become more selective with respect to education (Table 5). ${ }^{9}$ In Los Angeles County, for instance, the proportion of Mexican migrant "settlers" (USC-COLEF Household Survey) who had at least 10 years of education rose from approximately 3 percent for the 1970-74 migrant cohort to over 16 percent for the 1990-92 cohort. The increase for their sojourner (USC-COLEF Mobile Population Survey) counterparts was from 25 percent to 49 percent. Evidence from the UCSD surveys in San Diego County also shows a rise in the educational attainment of more recent Mexican migrant cohorts. The proportion with more than 10 years of education has been on the rise since the mid-1980s, and the share of migrants with 
more than 4 years of education has risen from 80 to approximately 89 percent. Meanwhile, the proportion of those with less than four years has been declining since 1970. These data contradict the dominant perception of declining Mexican educational attainment, as does a recent nationallevel analysis by Smith (1998), based on U.S. Census data, showing that the "education deficit" between Mexican male immigrants and U.S.-born white men declines across generations.

Evidence gathered in rural Mexican sending communities also indicates rising educational levels among U.S.-bound migrants. For example, in one high-emigration town in Jalisco state surveyed three times by Cornelius, mean years of education among recent male migrants to the United States rose from 3.09 in 1976, to 4.25 in 1988, and to 4.75 in 1995 (Cornelius 1976, 1991, 1998a). Moreover, in each of these surveys, migrants to the U.S. had higher levels of educational attainment than the community mean. Thus, recent migrants to the United States appear to be more selective, in terms of the educational levels of their communities of origin, than they were twenty years ago.

\section{Regional Origins}

Available data show that four Mexican states - Jalisco, Michoacán, Guanajuato, and Coahuila - sent an estimated 54.5 percent of all Mexican migrants to the United States in 1924 and that the first three of these states and Zacatecas consistently appear in the top-eight sending states from the 1920s through the 1980s. Thus, four Mexican states -- Jalisco, Michoacán, Guanajuato, and Zacatecas -- can reasonably be considered the "historic" or "traditional" source region for migrants to the United States. ${ }^{10}$ Consistent with data gathered for the Mexico-United States Binational Migration Study (U.S. Commission on Immigration Reform and Mexican Ministry of Foreign Relations 1997), Durand, Massey and Zenteno (2001) show that, relative to the 1970s, the geographical origins of the Mexican migrant flow had shifted in a southeasterly direction, toward the center of the country.

Cornelius (1992: 157-165) cites evidence indicating that from the early 1970s to the late 1980s the Mexican migration flow became more diversified in terms of sending communities and regions. A survey of Mexicans employed in San Diego County in 1987-1988 found that about 38 percent had originated in either Jalisco or Michoacán (historically the top two sending states), but only 22 percent among migrants arriving since 1986 were Jalisciences or Michoacanos. The same survey also showed an increasing share coming from the Mexico City metropolitan area, i.e., the Federal District and contiguous municipalities in the Estado de México. Durand, Massey and Zenteno (2001) also found that the proportion of migrants originating in Jalisco and Michoacán 
had declined, from 22 to 18 percent, and that the share of migrants coming from what they define as the "historic" region of emigration to the United States (Aguascalientes, Colima, Durango, Guanajuato, Jalisco, Michoacán, Nayarit, San Luis Potosí, and Zacatecas) fell from 57 to 49 percent. ${ }^{11}$ However, when comparing with the pre-1975 entry cohort, Durand, Massey and Zenteno (2001) find no clear temporal trend. Forty-nine percent of the 1990-92 migrant cohort traveled from the "historic" region, while 48 percent of the 1970-74 cohort had originated there.

Interpretations of longitudinal place-of-origin analyses depend on at least three factors. First, prior to 1979 no national representative sample of migrants to the United States existed in Mexico (García y Griego 1983). Thus, comparisons made using Mexican data before this time are based on data obtained from specific regions and cannot lead to firm conclusions about the entire migrant flow (García y Griego 1989: 53). Second, even if representative data existed for the pre-1979 period, conclusions about the changing regional origins of Mexican migrants depend on the chosen reference time period. For example, as noted above, comparing the proportion of Mexican migrants coming from the "historic" region in the 1990-92 arrival cohort (48.8 percent) with those who arrived between 1975-79 (57.4 percent) versus those who arrived between 1970-74 (47.8 percent) produces conflicting results. The former comparison supports what most research has shown; the latter, the notion of an unchanging regional origins profile. Third, differences in the way in which source regions are defined may also contribute to contradictory findings. Applying Durand, Massey and Zenteno's (2001) regional definitions to the 1996 UCSD data and 1994 USC-COLEF Mobile Population data, we find significant shifts in the regional origins of Mexican migrants since 1970 (Table 6). ${ }^{12}$

\section{$<$ TABLE 6 ABOUT HERE $>>$}

The San Diego data, for example, show that the proportion coming from the nine states used to define the historic region fell steadily from the 1975-79 migrant cohort to the 1990-92 cohort. The share of those originating in Mexico's border region fell even more sharply, from 67.7 to 25.7 percent, while the proportion of those from the center and periphery regions (combined) rose from 11.8 to 51.4 percent during the same period. A similar trend can be seen in the 1994 Los Angeles County mobile population survey data. From the 1970-74 migrant cohort to the 1990-92 cohort, the proportion coming from the historic region declined, while the share of migrants from the center and periphery regions increased sharply, and those coming from the border region fell drastically. Both data sets are consistent with the notion of a relatively constant 
(but declining) flow emanating from the historic region; however, they also suggest there has been a considerable southeasterly shift in the regional sources of Mexico-to-U.S. migration.

\section{$<<$ TABLE 7 ABOUT HERE $>>$}

Applying alternative regional origin definitions (that further divide the center and periphery regions) to the Los Angeles and San Diego County data reveals similar results (Table 7). Again, because we are using exactly the same definitions for the "historic" and "border" regions as in Figure 6, we see a gradually declining proportion of Mexican migrants originating from the former region and a rapid decline in the proportion of migrants from the border region. What a more detailed breakdown of the center and periphery regions illustrates, then, is an increasingly important role being played by Mexico's southern region (especially the states of Guerrero, Oaxaca, and Chiapas) and by the Mexico City metropolitan area. In both San Diego and Los Angeles Counties, the shift in origins away from the border and historic regions is being led by migrants born in the south and the Mexico City metropolitan area.

\section{Urban-Rural Composition}

Urbanization in Mexico, whether a result of a diffused geographical modernization process or led by the Mexico City megalopolis (Ward 1998), has been rapid since the 1960s. Defining urban places as those having a population of 5,000 or more, less than 40 percent of Mexico's population lived in urban areas in the late $19^{\text {th }}$ century. The pace of urbanization was moderate until just before World War II, but by 1970 about 60 percent of the population was living in urban areas, and by 1990 approximately 70 percent were urban-dwellers (Easterlin 1996: 35). By the mid-1990s, over half of the Mexican population was living in cities of more than 100,000 inhabitants.

Controlling for age composition, Durand, Massey, and Zenteno (2001) report that while 53.6 percent of Mexican labor migrants who left Mexico between 1970 and 1974 were born in a city of more than 15,000 persons, only 43.1 percent of those departing between 1985 and 1990 were. $^{13}$ Thus, contrary to Cornelius' (1992) analysis, they argue that the Mexico-to-U.S. migration flow is not becoming more dominated by urban-dwellers. This claim is contradicted by more recent data from southern California.

$<<$ TABLE 8 ABOUT HERE $>>$ 
While the results are not perfectly comparable due to a small difference in the rural/urban threshold used in coding the data, the proportion of Mexicans in the 1996 UCSD surveys who entered the United States between 1970 and 1974 and were born in a locality of more than 10,000 inhabitants was 53.1 percent (Table 8). This figure rose to 71.4 percent for those who entered in the 1990-92 cohort. The trend toward urban origins has been even stronger among Mexican migrants to Los Angeles County. More than 80 percent of the 1990-92 entry cohort in the USC-COLEF mobile population survey had migrated from an urban area. ${ }^{14}$ In sum, our data from Los Angeles and San Diego suggest that both migrant settlers and sojourners, albeit reflecting continuing urbanization in Mexico, have a tendency to come more from urban rather than rural areas of Mexico.

\section{Predicting Permanent Settlement}

We saw above that the intention to settle permanently in the United States and the feminization of the Mexican migrant flow are positively related. However, to test more fully Cornelius' (1992) hypotheses about what explains the changing demographic profile of Mexican migrants to the United States, we ran six logistic regressions using data from the 1996 San Diego County surveys.

\section{$<<$ TABLE 9 ABOUT HERE $>>$}

The results, reported in Table 9, suggest that only two demographic variables (being female and length of residence in the United States) are consistently, positively, and significantly related to reported intention to settle in the United States. For readers not familiar with logistic regression analysis, by converting the parameter coefficients in column 6 into probabilities, we find that one is 35 percent more likely to reside permanently in the United States on average if female, and 2 percent more likely with each additional year having resided in the United States. ${ }^{15}$

Furthermore, controlling for all demographic variables and regardless of whether they are included separately or collectively, of Cornelius's (1992) four hypothesized explanations for a changing Mexican migrant profile, only the IRCA amnesty provision appears not to have had a significant effect on individual migrants' intentions to settle in the United States. Having migrated during the Mexican economic crisis of the 1980s, year-round employer demand for labor (i.e., holding a non-seasonal job that provides steady employment), and belonging to a social network that includes U.S.-born friends are all significant explanations of intention to 
settle in the United States. Again, converting these parameter coefficients into probabilities, we find that a person who migrated to the United States during a period of economic crisis in Mexico is 19 percent more likely to reside permanently in the United States on average, those with a close U.S.-born friend are 23 percent more likely, and a paucity of work opportunities reduces one's likelihood of residing permanently by 15 percent on average.

These findings are consistent with the argument made by Bryan Roberts and others that "the current economic situation in both rural and urban Mexico is promoting a permanent migration system. Scarcities of jobs and declines in real income for the rural population and for the poorest 40 percent of the urban population make it increasingly difficult to find a stable subsistence base in either countryside or city...The [growing] demand in the U.S. for year-round, low-skilled labor in construction, urban services, and 'sweat-shop' manufacturing creates the complementary basis for a permanent migration system" (Roberts, Frank, and Lozano-Asencio 1999: 243).

\section{DISCUSSION AND POLICY IMPLICATIONS}

The distinction between an immigrant sojourner and settler was first elaborated by labor economist Michael Piore in his Birds of Passage: Migrant Labor and Industrial Societies (1979). Sojourners were defined as those who, after accumulating a certain amount of money, would return to the country of origin; settlers were those who intended to remain in the destination country. This distinction remains essential for understanding the effects of immigration and what kinds of U.S. immigration and immigrant policies are more likely to succeed (Fix and Passel 1994; Mameesh and Reyes 1998). It has also gained importance in light of increased U.S. immigration over the past three decades, given that "the consequences of net immigration to society are much more important than the consequences of immigration per se" (Heer 1996: 112). Clearly migrants who settle in the United States are more likely to affect the U.S. political economy than are return migrants (Cornelius, 1981; García y Griego 1983).

The proportion of migrants settling in the United States, however, is only part of the story. Thoughtful discussions of settlement patterns tend to focus on the demographic and socioeconomic characteristics of newcomers who are likely to become long-term residents of the United States. This broader picture, or profile, of more recent immigrant cohorts is essential for accurately estimating their likely socioeconomic impacts on the receiving areas. For example, the Mexico-United States Binational Migration Study - the first migration research project sponsored 
by the two governments, and conducted by a team of ten Mexican and ten U.S. immigration experts - begins with an important caveat: Although much of the recent debate concerning Mexican migration to the United States centers on the difficult task of obtaining reliable stock and flow estimates of the number of Mexican migrants, they are not a homogenous group, and recognition of their internal differences is essential for a responsible evaluation of the impacts on source and destination societies (Bean, Corona, Tuirán and Woodrow-Lafield 1998:1-2).

The importance of both quantity and "quality" to the contemporary U.S. immigration debate cannot be overstated. An estimated 100,000-200,000 undocumented immigrants entered and settled annually in California during the 1980s and early 1990s (Marcelli 2001), and between 1992-1996 an average of 275,000 did so nationally (Warren 1997). The foreign-born Mexican contribution to the total net migrant flow into the United States almost doubled, from about 12 percent during the 1950s to approximately 23 percent during the 1980s (Borjas 1997). By comparison, Mexicans constituted about 28 percent of all those who have entered the U.S. and settled in the 1990s. ${ }^{16}$ These contributions to population growth resulted in slightly more than seven million foreign-born Mexicans residing in the United States by 1997, representing 2.74 percent of the total population, up from 1.7 percent in 1990 and 1.0 percent in 1980.

That Mexican immigrants remain such a small component of the total U.S. population suggests that it has been their characteristics and geographic concentration that has generated concern about their numbers. Perhaps the most telling indication has been the disproportionate concern for the socioeconomic impact of low-skilled and poor immigrants versus high-skilled and wealthier immigrants. Borjas (1997, 1998), for example, argues that recent cohorts of Mexican immigrants have comparatively meager human capital endowments, have adversely affected the earnings of similarly skilled U.S.-born workers, and have a relatively high rate of welfare use. However, evidence to the contrary is mounting regarding the effects of unauthorized Mexican immigrants on the employment and wages of U.S.-born residents (Hanson, Robertson, and Spilimbergo 2000; Marcelli 1999; Marcelli, Pastor and Joassart 1999; Marcelli and Heer 1997) and on welfare expenditures (Marcelli and Heer 1998). ${ }^{17}$ For purposes of this paper, the key issue is not which set of fiscal- and labor market-impact findings is more accurate. Instead, it is that the content of the debate now focuses more on the human capital endowments that Mexican migrants carry with them across the border, their rate of permanent settlement, and their economic effects on other segments of the U.S. population rather than simply how many migrate north (Smith and Edmonston, eds. 1997, 1998; Hamermesh and Bean, eds. 1998). 
The passage of both California's restrictive immigration ballot initiative (Proposition 187) in 1994 and the federal Illegal Immigration Reform and Immigrant Responsibility Act (IIRIRA) of 1996 owes much to the widely-held notion that unauthorized Mexican immigrants impose excessive socioeconomic costs -- precisely because of their lower labor market skills and putative negative economic effects on schools, social services, welfare assistance, and the earnings of similarly skilled U.S.-born residents (MacDonald and Cain 1998). Clark (1998) takes the argument a step further, by highlighting the disproportionate birth and population density effects that persons of Mexican origin already residing in the United States are likely to have, well into the future. The implication is that because former Mexican migrant cohorts contributed significantly to the higher fertility rates of the current resident U.S. Mexican origin population, one may reasonably expect newer cohorts to have the same effect.

Yet another leading indicator that migrant characteristics matter as much or more than sheer numbers is that, increasingly, the U.S. immigration policy debate has focused on specific skill groups. For instance, soon after passage of IIRIRA in September 1996, proposals were introduced in Congress to increase the importation of both high-skilled (H-1B visa) and lowskilled (H-2A) foreign-born workers. ${ }^{18}$ While agribusiness interests pushed unsuccessfully for a new, modestly-scaled nonimmigrant guestworker program that would have raised the number of workers permitted to enter the U.S. each year to harvest crops from approximately 15,000 (FY 1996) to 20,000, high-technology firms successfully sought legislation increasing the number of visas from 65,000 to 115,000 per annum for computer programmers and other technologically high-skilled workers. Claims of actual or impending shortages of both "high-end" computer industry workers and "low-end" agricultural labor were immediately challenged by immigration restriction advocacy groups and U.S. government researchers (U.S.G.A.O. 1997).

Of immediate concern, however, is not whether there will be a shortage of lower- or higher-skilled labor in the near future that international migration may help to ameliorate, but that the characteristics of Mexican migrants have become central to the ongoing immigration debate. While there is more certainty concerning the estimated number of unauthorized and legal Mexican immigrants residing in the United States than about their individual characteristics and economic impacts on native-born residents (Bean, Corona, Tuirán, and Woodrow-Lafield 1998), the latter set of concerns has come to dominate public discourse on U.S. immigration policy (K. Lee 1998; Marcelli, Pastor, and Joassart 1999).

The immigration policy debate is complicated by continuing academic debates over empirical questions, as demonstrated by the major inconsistencies in research findings 
concerning the demographic profile of Mexican migrants to the United States that we highlight in this paper. Specifically, while Durand, Massey, and Zenteno (2001) provide evidence suggesting that more recent Mexican migrant cohorts are very similar to past cohorts in terms of gender, age, and educational composition, propensity to settle permanently in the United States, and regional origin, we show the exact opposite. The discrepancy may be explained partly by the fact that they and we use different data, but it may also be a byproduct of underlying theoretical perspectives. We have highlighted two theoretical orientations - cumulative causation and a migration systems approach. While Durand, Massey, and Zenteno's (2001) evidence seems to support a cumulative causation framework, we have found that both theories have some explanatory merit. The likelihood of Mexican migrants settling permanently in southern California was found to be significantly influenced by economic crisis in Mexico and the U.S. demand for Mexican migrant labor (a migration systems approach) as well as having a U.S.-born friend (cumulative causation). That we did not find greater social network effects, however, indicates that our results are more consistent with a migration-systems theoretical perspective in general. ${ }^{19}$

While we suspect that these findings, based on data gathered in southern California and Mexico, may apply throughout California and the United States - especially given their consistency with the results of survey and ethnographic studies in the U.S. South, the New York City area (R. Smith 1998), and other regions - we cannot confidently make such an assertion based on the present analysis. Has the demographic profile of Mexican migrants throughout California or the nation actually changed as our results suggest for southern California, in ways that affect the magnitude and distribution of costs and benefits associated with this migratory movement? Further research, conducted on both sides of the U.S.-Mexico border and preferably using more sophisticated, longitudinal research designs, is clearly needed to answer this basic question. 


\section{TABLE 1: Independent Variables Used in Permanent Settlement Logistic Regressions}

\section{Demographic Variables}

$\begin{array}{ll}\text { Female } & \text { Female }(\operatorname{Sex}=1) \\ \text { Age 25 or Lower } & \text { Person of age }<=25 \text { years } \\ \text { Age 26-35 } & \text { Person of age 26 to 35 } \\ \text { Age 36-45 } & \text { Person of age 36 to 45 } \\ \text { Age 55-65 } & \text { Person of age 55 to 65 (Excluded from Regressions) } \\ \text { Educ } & \text { Years of schooling completed } \\ \text { English } & \text { English comprehension (none=1, some=2, much=3) } \\ \text { Yrs_res } & \text { Years since first arriving in the United States }(=1996 \text { - arrival year) } \\ \text { Expct_US_yrs } & \text { Residing in U.S. longer than expected (yes=1, no=0) } \\ \text { Legal } & \text { Legal U.S. resident (yes=1, no=0) }\end{array}$

\section{Economic Crisis in Mexico}

EconCris $\quad$ Migrated to the U.S. between 1982 and 1987 (yes=1, no=0)

\section{IRCA Amnesty Provisions}

SAW Legal resident who migrated to U.S. before 1987 and whose first job was in agriculture (yes $=1$, no $=0$ )

Cont_Res72 Legal resident who migrated to U.S. before 1983 and has lived at least 9 months per year in U.S. on average (yes $=1$, no $=0$ )

\section{U.S. Demand for Labor}

LittleWork Are there months when there is little work? (yes=1, no=0)

\section{Social Networks}

Spouse_US Respondent resides with a spouse in the United States (yes $=1$, no $=0$ )

Child_6to18 Respondent resides with at least one child aged 6-18 years (yes $=1$, no $=0$ )

USB_Friend Respondent has friends born in the United States with whom they can speak when they have problems (yes $=1$, no $=0$ )

Note: Permannent Settlement is defined as the intention to reside in the United States. 
TABLE 2: Percent Female among Mexico-U.S. Migrants by Year of Departure

YEAR OF DEPARTURE

DATA SOURCE

$$
\text { 1970-74 }
$$

1975-79

1980-84

1985-89

1990-92

ENADID

42.0

38.6

35.5

31.9

$\mathbf{U C S D}^{\mathrm{b}}$

25.0

35.3

32.0

30.2

43.5

USC-COLEF $^{\mathrm{c}}$

46.9

41.6

40.7

46.5

56.2

Sources: (a) 1992 Mexican National Survey of Demographic Dynamics; (b) 1996 UCSD San Diego County Immigrant-dependent Business Establishment Survey; (c) 1994 USCCOLEF Los Angeles County Household Survey. 
TABLE 3: Percent Mexico-U.S. Migrants Identifying the United States as their Principal Country of Residence

\section{YEAR OF DEPARTURE}

DATA SOURCE

1970-74

1975-79

1980-84

1985-89

ENADID ${ }^{\mathrm{a}}$

19.6

22.4

25.7

37.7

$\mathbf{U C S D}^{\mathrm{b}}$

70.0

83.5

84.2

87.1

Sources: (a) 1992 Mexican National Survey of Demographic Dynamics; (b) 1996 UCSD San Diego County Immigrant-dependent Business Establishment Survey. 
TABLE 4: Percent of Mexico-U.S. Migrants Departing for the United States by Age at and Year of Departure

1. ENADID

\begin{tabular}{lccccc} 
& \multicolumn{5}{c}{ YEAR OF DEPARTURE } \\
AGE AT DEPARTURE & $\mathbf{1 9 7 0 - 7 4}$ & $\mathbf{1 9 7 5 - 7 9}$ & $\mathbf{1 9 8 0 - 8 4}$ & $\mathbf{1 9 8 5 - 8 9}$ & $\mathbf{1 9 9 0 - 9 2}$ \\
$\mathbf{1 2}$ to $\mathbf{1 8}$ & 13.8 & 11.2 & 14.6 & 11.7 & 8.9 \\
$\mathbf{1 9}$ to $\mathbf{3 4}$ & 55.9 & 60.7 & 60.6 & 63.3 & 56.8 \\
$\mathbf{3 5}$ to $\mathbf{5 4}$ & 28.7 & 24.4 & 22.4 & 22 & 30.2 \\
$\mathbf{5 5}+$ & 1.6 & 3.7 & 2.4 & 2.9 & 4.1
\end{tabular}

\section{USC-COLEF MOBILE POPULATION SURVEY}

\begin{tabular}{lccccc} 
& \multicolumn{5}{c}{ YEAR OF DEPARTURE } \\
AGE AT DEPARTURE & $\mathbf{1 9 7 0 - 7 4}$ & $\mathbf{1 9 7 5 - 7 9}$ & $\mathbf{1 9 8 0 - 8 4}$ & $\mathbf{1 9 8 5 - 8 9}$ & $\mathbf{1 9 9 0 - 9 2}$ \\
$\mathbf{1 2}$ to $\mathbf{1 8}$ & 24.0 & 23.6 & 11.6 & 31.8 & 22.6 \\
$\mathbf{1 9}$ to $\mathbf{3 4}$ & 76.0 & 45.5 & 86.9 & 58.3 & 73.0 \\
$\mathbf{3 5}$ to $\mathbf{5 4}$ & 0.0 & 30.9 & 0.9 & 4.7 & 4.4 \\
$\mathbf{5 5}+$ & 0.0 & 0.0 & 0.6 & 5.2 & 0.0
\end{tabular}

3. USC-COLEF HOUSEHOLD SURVEY

YEAR OF DEPARTURE

$\begin{array}{lccccc}\text { AGE AT DEPARTURE } & \mathbf{1 9 7 0 - 7 4} & \mathbf{1 9 7 5 - 7 9} & \mathbf{1 9 8 0 - 8 4} & \mathbf{1 9 8 5 - 8 9} & \mathbf{1 9 9 0 - 9 2} \\ \mathbf{1 2} \text { to } \mathbf{1 8} & 15.18 & 22.22 & 51.24 & 41.52 & 39 \\ \mathbf{1 9} \text { to } \mathbf{3 4} & 66.29 & 69.15 & 35.68 & 50.72 & 53.52 \\ \mathbf{3 5} \text { to } \mathbf{5 4} & 17.4 & 5.56 & 8.61 & 5.71 & 5.85 \\ \mathbf{5 5}+ & 1.13 & 3.07 & 4.46 & 2.05 & 1.63\end{array}$

\section{UCSD IMMIGRANT-DEPENDENT BUSINESS ESTABLISHMENT SURVEY}

$\begin{array}{lccccc}\text { AGE AT DEPARTURE } & \mathbf{1 9 7 0 - 7 4} & \mathbf{1 9 7 5 - 7 9} & \mathbf{1 9 8 0 - 8 4} & \mathbf{1 9 8 5 - 8 9} & \mathbf{1 9 9 0 - 9 2} \\ \mathbf{1 2} \text { to } \mathbf{1 8} & 23.5 & 32.1 & 28.6 & 15.7 & 21.4 \\ \mathbf{1 9} \text { to } \mathbf{3 4} & 64.7 & 64.3 & 63.4 & 72.5 & 67.9 \\ \mathbf{3 5} \text { to } \mathbf{5 4} & 8.8 & 3.6 & 7.1 & 11.8 & 10.7 \\ \mathbf{5 5}+ & 2.9 & 0.0 & 0.9 & 0.0 & 0.0\end{array}$


TABLE 5: Educational Attainment of Mexico-U.S. Migrants by Year of Departure, Percent 1. ENADID

\begin{tabular}{lccccc} 
& \multicolumn{5}{c}{ YEAR OF DEPARTURE } \\
Educational Attainment & $\mathbf{1 9 7 0 - 7 4}$ & $\mathbf{1 9 7 5 - 7 9}$ & $\mathbf{1 9 8 0 - 8 4}$ & $\mathbf{1 9 8 5 - 8 9}$ & $\mathbf{1 9 9 0 - 9 2}$ \\
0 Years & 7.1 & 9.8 & 11.2 & 10.7 & - \\
1-4 Years & 11 & 15.2 & 17.3 & 17.9 & - \\
5-9 Years & 29.9 & 39.8 & 43.5 & 44.8 & - \\
10 or More Years & 52 & 35.1 & 28 & 26.5 & -
\end{tabular}

2. USC-COLEF MOBILE POPULATION SURVEY

\begin{tabular}{lccccc} 
& \multicolumn{5}{c}{ YEAR OF DEPARTURE } \\
Educational Attainment & $\mathbf{1 9 7 0 - 7 4}$ & $\mathbf{1 9 7 5 - 7 9}$ & $\mathbf{1 9 8 0 - 8 4}$ & $\mathbf{1 9 8 5 - 8 9}$ & $\mathbf{1 9 9 0 - 9 2}$ \\
0 Years & 4.7 & 7.1 & 3.8 & 5.8 & 1.5 \\
1-4 Years & 24.5 & 7.4 & 5.4 & 5.4 & 15.9 \\
5-9 Years & 45.5 & 56.1 & 60.9 & 32.3 & 33.4 \\
10 or More Years & 25.4 & 29.5 & 30.0 & 56.6 & 49.2
\end{tabular}

\section{USC-COLEF HOUSEHOLD SURVEY}

YEAR OF DEPARTURE

$\begin{array}{lccccc}\text { Educational Attainment } & \mathbf{1 9 7 0 - 7 4} & \mathbf{1 9 7 5 - 7 9} & \mathbf{1 9 8 0 - 8 4} & \mathbf{1 9 8 5 - 8 9} & \mathbf{1 9 9 0 - 9 2} \\ \text { 0 Years } & 0 & 0.7 & 0.1 & 0.2 & 3.8 \\ \text { 1-4 Years } & 84.6 & 71.9 & 61.2 & 68.5 & 57.1 \\ \text { 5-9 Years } & 12.3 & 11.9 & 35 & 27.7 & 22.9 \\ \text { 10 or More Years } & 3.1 & 15.5 & 4 & 3.6 & 16.2\end{array}$

\section{UCSD IMMIGRANT-DEPENDENT BUSINESS ESTABLISHMENT SURVEY}

\begin{tabular}{lccccc} 
& \multicolumn{5}{c}{ YEAR OF DEPARTURE } \\
Educational Attainment & $\mathbf{1 9 7 0 - 7 4}$ & $\mathbf{1 9 7 5 - 7 9}$ & $\mathbf{1 9 8 0 - 8 4}$ & $\mathbf{1 9 8 5 - 8 9}$ & $\mathbf{1 9 9 0 - 9 2}$ \\
0 Years & 5.0 & 2.4 & 2.0 & 3.7 & 4.4 \\
1-4 Years & 15.0 & 12.9 & 15.8 & 5.9 & 6.5 \\
5-9 Years & 35.0 & 50.6 & 51.5 & 50.7 & 41.3 \\
10 or More Years & 45.0 & 34.1 & 30.7 & 39.7 & 47.8
\end{tabular}


TABLE 6: Mexico-U.S. Migrants by Regional Origin and Year of Departure, Percent 1. ENADID

\begin{tabular}{lcrrrr} 
& \multicolumn{5}{c}{ YEAR OF DEPARTURE } \\
REGION & $\mathbf{1 9 7 0 - 7 4}$ & $\mathbf{1 9 7 5 - 7 9}$ & $\mathbf{1 9 8 0 - 8 4}$ & $\mathbf{1 9 8 5 - 8 9}$ & $\mathbf{1 9 9 0 - 9 2}$ \\
Historic & 47.8 & 57.4 & 56.1 & 49.5 & 48.8 \\
Border & 33.7 & 26.3 & 27.4 & 24.8 & 29.7 \\
Center & 17 & 13.8 & 15.2 & 24.6 & 19.8 \\
Periphery & 1.5 & 2.4 & 1.3 & 1.1 & 1.7
\end{tabular}

2. USC-COLEF MOBILE POPULATION SURVEY

\begin{tabular}{lcccrr} 
& \multicolumn{5}{c}{ YEAR OF DEPARTURE } \\
REGION & $\mathbf{1 9 7 0 - 7 4}$ & $\mathbf{1 9 7 5 - 7 9}$ & $\mathbf{1 9 8 0 - 8 4}$ & $\mathbf{1 9 8 5 - 8 9}$ & $\mathbf{1 9 9 0 - 9 2}$ \\
Historic & 33.9 & 32.5 & 21.2 & 21.2 & 19.0 \\
Border & 61.0 & 66.0 & 74.7 & 54.6 & 35.5 \\
Center & 5.2 & 0.6 & 4.1 & 23.9 & 43.2 \\
Periphery & 0.0 & 0.8 & 0.0 & 0.3 & 2.3
\end{tabular}

\section{UCSD IMMIGRANT-DEPENDENT BUSINESS ESTABLISHMENT SURVEY}

\begin{tabular}{lrrrrr} 
& \multicolumn{5}{c}{ YEAR OF DEPARTURE } \\
REGION & $\mathbf{1 9 7 0 - 7 4}$ & $\mathbf{1 9 7 5 - 7 9}$ & $\mathbf{1 9 8 0 - 8 4}$ & $\mathbf{1 9 8 5 - 8 9}$ & $\mathbf{1 9 9 0 - 9 2}$ \\
Historic & 20.6 & 37.0 & 33.3 & 29.6 & 22.9 \\
Border & 67.7 & 46.6 & 34.5 & 29.6 & 25.7 \\
Center & 11.8 & 16.4 & 29.9 & 39.1 & 51.4 \\
Periphery & 0.0 & 0.0 & 2.3 & 1.7 & 0.0
\end{tabular}


TABLE 7: Mexico-U.S. Migrants by Regional Origin and Year of Departure, Percent

1. USC-COLEF MOBILE POPULATION SURVEY

\begin{tabular}{lrrrrr} 
& \multicolumn{5}{c}{ YEAR OF DEPARTURE } \\
REGION & $\mathbf{1 9 7 0 - 7 4}$ & $\mathbf{1 9 7 5 - 7 9}$ & $\mathbf{1 9 8 0 - 8 4}$ & $\mathbf{1 9 8 5 - 8 9}$ & $\mathbf{1 9 9 0 - 9 2}$ \\
Historic & 33.9 & 32.5 & 21.2 & 21.2 & 19.0 \\
Border & 61.0 & 66.1 & 74.7 & 54.6 & 35.5 \\
Center & 0.0 & 0.0 & 0.2 & 0.0 & 1.6 \\
Mexico City / Metro Area & 5.2 & 0.0 & 3.7 & 14.3 & 39.4 \\
Periphery & 0.0 & 0.0 & 0.0 & 0.0 & 0.2 \\
South & 0.0 & 1.4 & 0.2 & 9.8 & 4.2
\end{tabular}

2. UCSD IMMIGRANT-DEPENDENT BUSINESS ESTABLISHMENT SURVEY

\begin{tabular}{lrrrrr} 
& \multicolumn{5}{c}{ YEAR OF DEPARTURE } \\
REGION & $\mathbf{1 9 7 0 - 7 4}$ & $\mathbf{1 9 7 5 - 7 9}$ & $\mathbf{1 9 8 0 - 8 4}$ & $\mathbf{1 9 8 5 - 8 9}$ & $\mathbf{1 9 9 0 - 9 2}$ \\
Historic & 20.6 & 37.0 & 33.3 & 29.6 & 22.9 \\
Border & 67.7 & 46.6 & 34.5 & 29.6 & 25.7 \\
Center & 2.9 & 5.5 & 9.2 & 12.2 & 22.9 \\
Mexico City / Metro Area & 5.9 & 4.1 & 5.8 & 17.4 & 14.3 \\
Periphery & 0.0 & 0.0 & 0.0 & 0.9 & 0.0 \\
South & 2.9 & 6.9 & 17.2 & 10.4 & 14.3
\end{tabular}


TABLE 8: Mexico-U.S. Migrants by Size/Type of Birthplace and Year of Departure, Percent

1. UCSD IMMIGRANT-DEPENDENT BUSINESS ESTABLISHMENT SURVEY

\section{YEAR OF DEPARTURE}

$\begin{array}{llllll}\text { POPULATION SIZE } & 1970-74 & 1975-79 & 1980-84 & 1985-89 & 1990-92\end{array}$

$\begin{array}{llllll}\mathbf{1 0 , 0 0 0} \text { or More } & 53.12 & 56.16 & 57.14 & 65.18 & 71.43\end{array}$

$\begin{array}{llllll}\text { Less than 10,000 } & 46.88 & 43.84 & 42.86 & 34.82 & 28.57\end{array}$

2. USC-COLEF MOBILE POPULATION SURVEY

\begin{tabular}{lccccc} 
& \multicolumn{5}{c}{ YEAR OF DEPARTURE } \\
REGION & $\mathbf{1 9 7 0 - 7 4}$ & $\mathbf{1 9 7 5 - 7 9}$ & $\mathbf{1 9 8 0 - 8 4}$ & $\mathbf{1 9 8 5 - 8 9}$ & $\mathbf{1 9 9 0 - 9 2}$ \\
Urban & 77.94 & 56.92 & 58.85 & 78.31 & 80.53 \\
Rural & 22.06 & 43.08 & 41.15 & 21.69 & 19.47
\end{tabular}


TABLE 9: Logistic Regression Analysis of Intention to Reside Permanently in the United States among Mexico-U.S. Migrants, San Diego County, 1996

\begin{tabular}{|c|c|c|c|c|c|c|}
\hline & 1 & 2 & 3 & 4 & 5 & 6 \\
\hline Female & $\begin{array}{l}1.2793 * * * \\
(0.2537)\end{array}$ & $\begin{array}{l}1.3123 * * * \\
(0.2571)\end{array}$ & $\begin{array}{l}1.2437 * * * \\
(0.2562)\end{array}$ & $\begin{array}{l}1.4336 * * * \\
(0.2749)\end{array}$ & $\begin{array}{l}1.3623 * * * \\
(0.2682)\end{array}$ & $\begin{array}{l}1.5880 * * * \\
(0.3009)\end{array}$ \\
\hline Age 25 or Lower & $\begin{array}{l}-0.8602 * \\
(0.4666)\end{array}$ & $\begin{array}{l}-0.7751 * \\
(0.4692)\end{array}$ & $\begin{array}{l}-0.8763 * \\
(0.4693)\end{array}$ & $\begin{array}{l}-0.9082 * \\
(0.5220)\end{array}$ & $\begin{array}{l}-0.7500 \\
(0.4830)\end{array}$ & $\begin{array}{l}-0.7900 \\
(0.5452)\end{array}$ \\
\hline Age $26-35$ & $\begin{array}{l}0.0998 \\
(0.3797)\end{array}$ & $\begin{array}{l}0.0009 \\
(0.3817)\end{array}$ & $\begin{array}{l}0.0892 \\
(0.3819)\end{array}$ & $\begin{array}{l}0.2424 \\
(0.4223)\end{array}$ & $\begin{array}{l}0.0312 \\
(0.3931)\end{array}$ & $\begin{array}{l}0.0173 \\
(0.4422)\end{array}$ \\
\hline Age $36-45$ & $\begin{array}{l}-0.1074 \\
(0.3716)\end{array}$ & $\begin{array}{l}-0.1179 \\
(0.3708)\end{array}$ & $\begin{array}{l}-0.1199 \\
(0.3740)\end{array}$ & $\begin{array}{l}-0.0598 \\
(0.4096)\end{array}$ & $\begin{array}{l}-0.0219 \\
(0.3848)\end{array}$ & $\begin{array}{l}-0.0312 \\
(0.4281)\end{array}$ \\
\hline Educ & $\begin{array}{l}0.0470 \\
(0.0326)\end{array}$ & $\begin{array}{l}0.0554 \\
(0.0331)\end{array}$ & $\begin{array}{l}0.0432 \\
(0.0329)\end{array}$ & $\begin{array}{l}0.0544 \\
(0.0381)\end{array}$ & $\begin{array}{l}0.0622 * \\
(0.0340)\end{array}$ & $\begin{array}{l}0.0728 * \\
(0.0404)\end{array}$ \\
\hline English & $\begin{array}{l}0.3745 * * \\
(0.1905)\end{array}$ & $\begin{array}{l}0.3141 * \\
(0.1934)\end{array}$ & $\begin{array}{l}0.3459 * \\
(0.1922)\end{array}$ & $\begin{array}{l}0.3931 * \\
(0.2216)\end{array}$ & $\begin{array}{l}0.1356 \\
(0.2056)\end{array}$ & $\begin{array}{l}0.1303 \\
(0.2436)\end{array}$ \\
\hline Yrs_res & $\begin{array}{l}0.0561 * * * \\
(0.0173)\end{array}$ & $\begin{array}{l}0.0645 * * * \\
(0.0177)\end{array}$ & $\begin{array}{l}0.0588 * * * \\
(0.0180)\end{array}$ & $\begin{array}{l}0.0643 * * * \\
(0.0208)\end{array}$ & $\begin{array}{l}0.0532 * * * \\
(0.0180)\end{array}$ & $\begin{array}{l}0.0745^{* * * *} \\
(0.0228)\end{array}$ \\
\hline Expct_US_res & $\begin{array}{l}-0.2439 \\
(0.2151)\end{array}$ & $\begin{array}{l}-0.3112 \\
(0.2189)\end{array}$ & $\begin{array}{l}-0.2306 \\
(0.2159)\end{array}$ & $\begin{array}{l}-0.3113 \\
(0.2446)\end{array}$ & $\begin{array}{l}-0.2152 \\
(0.2242)\end{array}$ & $\begin{array}{l}-0.3605 \\
(0.2592)\end{array}$ \\
\hline Legal & $\begin{array}{l}0.2076 \\
(0.2320)\end{array}$ & $\begin{array}{l}0.1780 \\
(0.2340)\end{array}$ & $\begin{array}{l}0.3542 \\
(0.2895)\end{array}$ & $\begin{array}{l}0.3068 \\
(0.2578)\end{array}$ & $\begin{array}{l}0.2955 \\
(0.2429)\end{array}$ & $\begin{array}{l}0.3501 \\
(0.3464)\end{array}$ \\
\hline EconCris & & $\begin{array}{l}0.6245 * * * \\
(0.2364)\end{array}$ & & & & $\begin{array}{l}0.8048 * * * \\
(0.2822)\end{array}$ \\
\hline SAW & & & $\begin{array}{l}-0.4960 \\
(0.3807)\end{array}$ & & & $\begin{array}{l}-0.2686 \\
(0.4386)\end{array}$ \\
\hline Cont_Res72 & & & $\begin{array}{l}0.0649 \\
(0.3832)\end{array}$ & & & $\begin{array}{l}0.2106 \\
(0.4433)\end{array}$ \\
\hline LittleWork & & & & $\begin{array}{l}-0.5140^{* *} \\
(0.2403)\end{array}$ & & $\begin{array}{l}-0.6372 * * \\
(0.2527)\end{array}$ \\
\hline Spouse_US & & & & & $\begin{array}{l}0.0223 \\
(0.2351)\end{array}$ & $\begin{array}{l}-0.1483 \\
(0.2609)\end{array}$ \\
\hline Child_6to18 & & & & & $\begin{array}{l}0.1085 \\
(0.2430)\end{array}$ & $\begin{array}{l}0.0251 \\
(0.2702)\end{array}$ \\
\hline USB_Friend & & & & & $\begin{array}{l}0.8049 * * * \\
(0.2379)\end{array}$ & $\begin{array}{l}0.9389 * * * \\
(0.2707)\end{array}$ \\
\hline Intercept & $\begin{array}{l}-1.4538 * * * \\
(0.5144)\end{array}$ & $\begin{array}{l}-1.6917 * * * \\
(0.5270)\end{array}$ & $\begin{array}{l}-1.4125 * * * \\
(0.5195)\end{array}$ & $\begin{array}{l}-1.5220^{* *} \\
(0.6164)\end{array}$ & $\begin{array}{l}-1.9157 * * * \\
(0.5524)\end{array}$ & $\begin{array}{l}-2.2085^{* * * *} \\
(0.6708)\end{array}$ \\
\hline Unweughted N & 470 & 470 & 470 & 390 & 457 & 385 \\
\hline Pseudo R2 & 0.1426 & 0.1535 & 0.1452 & 0.1623 & 0.1638 & 0.2055 \\
\hline
\end{tabular}

Notes: Parameter coefficients, which may be quickly converted into probabilities, are reported rather than odds ratios (see note number 16 for explanation and text for examples); numbers in parentheses are standard errors; the symbol $" * * * "$ indicates a significance level of $.01, " * * *$ implies a significance level of .05 , and "*" denotes a signficance level of .10 . 


\section{REFERENCES}

\section{ALARCÓN, RAFAEL}

1995a "Immigrants or Transnational Workers? The Settlement Process Among Mexicans in Rural California." Davis, CA: California Institute for Rural Studies.

1995b "Transnational Communities, Regional Development, and the Future of Mexican Immigration," Berkeley Planning Journal 10: 36-54.

BEAN, FRANK D., RODOLFO CORONA, RODOLPHO TUIRÁN AND KAREN A. WOODROW-LAFIELD

1998 "The Quantification of Migration between Mexico and the United States," In Migration Between Mexico and the United States: Binational Study, Vol. 1, 1-89. Mexico City and Washington, D.C.: Mexican Ministry of Foreign Affairs and U.S. Commission on Immigration Reform.

BEAN, FRANK D., THOMAS J. ESPENSHADE, MICHAEL J. WHITE, AND ROBERT F. DYMOWSKI

1990 "Post-IRCA Changes in the Volume and Composition of Undocumented Migration to the United States: An Assessment Based on Apprehensions Data," In Undocumented Migration to the United States: IRCA and the Experience of the 1980s, edited by Frank D. Bean, Barry Edmonston, and Jeffrey S. Passel, 111-158. Santa Monica, CA: RAND and Washington, D.C.: The Urban Institute.

\section{BORJAS, GEORGE J.}

1997 “The Economic Impact of Mexican Immigration,” In Coming Together?: MexicoUnited States Relations, edited by Barry Bosworth, Susan M. Collins and Nora Claudia Lustig, 155-186. Washington, D.C.: Brookings Institution Press.

1998 "Immigration and Welfare: A Review of the Evidence," In The Debate in the United States over Immigration, edited Peter Duignan and L.H. Gann. Stanford, CA: Hoover Institution Press.

\section{BUSTAMANTE, JORGE A.}

1984 "Changing Patterns of Undocumented Migration from Mexican States in Recent Years," In Patterns of Undocumented Migration:Mexico and the United States, edited by Richard C. Jones, 15-32. Totowa, NJ: Rowman and Allanheld.

\section{CASTLES, STEPHEN AND MARK J. MILLER}

1998 The Age of Migration: International Population Movements in the Modern World. New York: The Guilford Press.

\section{CHAVEZ, LEO R.}

1988 "Settlers and Sojourners: The Case of Mexicans in the United States," Human Organization 47, no. 2: 95-198.

CLARK, WILLIAM A.V.

1998 The California Cauldron: Immigration and the Fortunes of Local Communities. New York: Guilford Press.

\section{CORNELIUS, WAYNE A.}

1976 "Outmigration from Rural Mexican Communities," in The Dynamics of Migration: International Migration. Occasional Monograph Series, no. 5, vol. 2. Washington, D.C.: Interdisciplinary Communications Program, Smithsonian Institution. 
1981 "The Future of Mexican Immigrants in California: A New Perspective for Public Policy." Working Papers in U.S.-Mexican Studies, No. 6. La Jolla, Calif.: Center for U.S.-Mexican Studies, University of California-San Diego.

1991 "Labor Migration to the United States: Development Outcomes and Alternatives in Mexican Sending Communities," in Regional and Sectoral Development in Mexico as Alternatives to Migration, edited by Sergio Díaz-Briquets and Sidney Weintraub. Boulder, Col.: Westview.

1992 "From Sojourners to Settlers: The Changing Profile of Mexican Immigration to the United States," In U.S.-Mexico Relations: Labor Market Interdependence, edited by Jorge A. Bustamante, Clark W. Reynolds, and Raúl Hinojosa-Ojeda, 155-195. Stanford, CA: Stanford University Press.

1998a "Ejido Reform: Stimulus or Alternative to Migration," in The Transformation of Rural Mexico: Reforming the Ejido Sector, edited by Wayne A. Cornelius and David Myhre, 229-246. La Jolla, Calif.: Center for U.S.-Mexican Studies, University of California-San Diego.

1998b "The Structural Embeddedness of Demand for Mexican Immigrant Labor: New Evidence from California," in Crossings: Mexican Immigration in Interdisciplinary Perspectives, edited by Marcelo Suárez-Orozco, 113-144. Cambridge, MA: Harvard University Press.

\section{DURAND, JORGE}

1998 "Migration and Integration: Intermarriages among Mexicans and Non-Mexicans in the United States," In Crossings: Mexican Immigration in Interdisciplinary Perspectives, edited by Marcelo M. Suárez-Orozco, 209-221. Cambridge, MA: Harvard University Press.

\section{DURAND, JORGE, AND DOUGLAS S. MASSEY}

1992 "Mexican Migration to the United States: A Critical Review," Latin American Research Review 27, no. 2: 3-42.

DURAND, JORGE, DOUGLAS S. MASSEY, AND RENÉ M. ZENTENO

2001 "Mexican Immigration to the United States: Continuities and Changes," Latin American Research Review 36(1): 107-126.

\section{EASTERLIN, RICHARD A.}

1996 Growth Triumphant: The Twenty-first Century in Historical Perspective. Ann Arbor, MI: The University of Michigan Press.

\section{FIX, MICHAEL AND JEFFREY S. PASSEL}

1994 Immigration and Immigrants: Setting the Record Straight. Washington, D.C.: The Urban Institute.

FREEMAN, GARY P., SUSAN GONZÁLEZ-BAKER, MANUEL OROZCO, AND LUIS

\section{F.B. PLASCENCIA}

1999 "The Making of Americans: Results of the Texas Naturalization Survey." Unpublished paper, Public Policy Clinic, Department of Government, University of Texas-Austin.

\section{GARCÍA Y GREIGO, MANUEL}

1989 “The Mexican Labor Supply, 1990-2010," In Mexican Migration to the United States: Origins, Consequences, and Policy Options, edited by Wayne A. Cornelius and Jorge A. Bustamante, 49-93. La Jolla, CA: UCSD Center for U.S-Mexican Studies. 
1983 "Comments on Bustamante and Sanderson Papers and on Research Project ENEFNEU," In U.S.-Mexico Relations: Economic and Social Aspects, edited by Clark W. Reynolds and Carlos Tello, 299-314. Stanford: Stanford University Press.

\section{HAMERMESH, DANIEL S. AND FRANK D. BEAN, EDS.}

1998 Help or Hindrance: The Economic Implications of Immigration for African Americans. New York: Russell Sage Foundation.

HANSON, GORDON H., RAYMOND ROBERTSON, AND ANTONIO SPILIMBERGO

2000 "Does Border Enforcement Protect U.S. Workers from Illegal Immigration?" Unpublished paper, Dept. of Economics, University of Michigan, and National Bureau of Economic Research.

\section{HEER, DAVID M.}

2000 "When Cumulative Causation Conflicts with Saturation of Economic Opportunity: Recent Change in the Hispanic Population of the United States by State," Paper presented at the annual meetings of the Population Association of America, March 24, 2000, Los Angeles.

1996 Immigration in America's Future: Social Science Findings and the Policy Debate. Boulder, CO: Westview Press.

\section{HERNANDEZ-LEON, RUBEN AND VICTOR ZUNIGA}

2000 "Making Carpet by the Mile: The Emergence of a Mexican Immigrant Community in an Industrial Region of the U.S. Historic South," Social Science Quarterly, 81, no. 1 (March): 49-66.

\section{HIRSCH, JENNIFER S.}

1998 "En el norte la mujer manda: Gender, Generation, and Geography in a Mexican Transnational Community." Paper presented at the XXI International Congress of the Latin American Studies Association, Chicago, Illinois, September 24-26.

\section{HONDAGNEU-SOTELO, PIERRETTE}

1994 Gendered Transitions: Mexican Experiences of Immigration. Berkeley, CA: University of California Press.

1997 "The History of Mexican Undocumented Settlement in the United States," in Romero, Mary, Pierrette Hondagneu-Sotelo, and Vilma Ortiz (eds.), Fronteras: Structuring Latina and Latino Lives in the U.S. New York: Routledge.

\section{JOHNSON, HANS}

1996 Undocumented Immigration to California: 1980-1993. San Francisco, CA: Public Policy Institute of California.

\section{KRITZ, MARY M., LIN LEAN LIM, AND HANIA ZLOTNIK}

1992 International Migration Systems: A Global Approach. Oxford: Clarendon Press. LEE, DON

1998 "Labor Supply Falling Short: Small Business Survey," The Los Angeles Times, 23 September, pp. D1, D6.

\section{LEE, KENNETH E.}

1998 Huddled Masses, Muddled Laws: Why Contemporary Immigration Policy Fails to Reflect Public Opinion. Westport, CT: Praeger.

\section{MABOGUNJE, A.L.}

1970 "A Systems Approach to a Theory of Rural-Urban Migration," Geographic Analysis 2: $1-18$. 


\section{MACDONALD, KARIN, AND BRUCE E. CAIN}

1998 "Nativism, Partisanship, and Immigration: An Analysis of Prop. 187," in Racial and Ethnic Politics in California, Vol. II., edited by Michael B. Preston, Bruce E. Cain, and Sandra Bass, 277-304. Berkeley, CA: Institute of Governmental Studies, University of California-Berkeley.

\section{MALKIN, VICTORIA}

1999 "La reproducción de relaciones de género en la comunidad de migrantes mexicanos en New Rochelle, Nueva York," in Fronteras Fragmentadas, edited by Gail Mummert, 475-496. Zamora and Morelia, Michoacán: El Colegio de Michoacán and Centro de Investigación y Desarrollo del Estado de Michoacán.

\section{MAMEESCH, LAURA AND BELINDA I. REYES}

1998 Regional Variation of Mexican Immigration and Settlement. San Francisco: Public Policy Institute

\section{MARCELLI, ENRICO A.}

1999 "Undocumented Latino Immigrant Workers: The Los Angeles Experience." In Illegal Immigration in America: A Reference Handbook, edited by David W. Haines and Karen E. Rosenblum, 193-231. Westport, CT: Greenwood Press.

\section{MARCELLI, ENRICO A. AND DAVID M. HEER}

1997 "Unauthorized Mexican Workers in the 1990 Los Angeles County Labour Force," International Migration 35, no. 1: 59-83.

1998 "The Unauthorized Mexican Immigrant Population and Welfare in Los Angeles County: A Comparative Statistical Analysis," Sociological Perspectives 41, no. 2: 279-302.

\section{MARCELLI, ENRICO A., MANUEL PASTOR, JR. AND PASCALE M. JOASSART}

1999 "Estimating the Effects of Informal Economic Activity: Evidence from Los Angeles County," Journal of Economic Issues 33, no. 3:579-607.

\section{MASSEY, DOUGLAS S.}

1990 "Social Structure, Household Strategies, and the Cumulative Causation of Migration," Population Index 56: 3-26.

1998 "March of Folly: U.S. Immigration Policy After NAFTA," The American Prospect, March-April.

MASSEY, DOUGLAS S., JOAQUN ARANGO, GRAEME HUGO, ALI KOUAOUCI, ADELA PELLEGRINO, AND J. EDWARD TAYLOR

1999 Worlds in Motion: Understanding International Migration at the End of the Millennium. Oxford: Clarendon Press.

\section{MYERS, DOWELL}

1998 "Dimensions of Economic Adaptation by Mexican-Origin Men," In Crossings: Mexican Immigration in Interdisciplinary Perspectives, edited by Marcelo SuárezOrozco, 159-200, Cambridge, MA: Harvard University Press.

MYRDAL, GUNNAR

1957 Rich Lands and Poor: The Road to World Prosperity. New York: Harper and Brothers Publishers.

\section{PIORE, MICHAEL}

1979 Birds of Passage: Labor Migration and Industrial Societies. London: Cambridge University Press. 


\section{PORTES, ALEJANDRO AND JOSEF BOROCZ}

1987 "Contemporary Immigration: Theoretical Perspectives on Its Determinants and Modes of Incorporation," International Migration Review 23: 606-630.

REES, MARTHA W., T. DANYAEL MILLER, AND MARIPOSA ARILLO

1997 "Latina Households and Work in Atlanta." Paper presented at the XXI International Congress of the Latin American Studies Association, Chicago, Illinois, September 2426.

ROBERTS, BRYAN R., REANNE FRANK, AND FERNANDO LOZANO-ASCENCIO

1999 "Transnational Migrant Communities and Mexican Migration to the United States," Ethnic and Racial Studies, Vol. 22 (2): 240-266.

ROSENBLUM, MARC R.

2000 "At Home and Abroad: The Foreign and Domestic Sources of U.S. Immigration Policy." Ph.D. dissertation, University of California-San Diego.

SASSEN, SAKIA

1988 The Mobility of Labor and Capital: A Study in International Investment and Labor Flow. New York: Cambridge University Press.

SMITH, JAMES P.

1998 "Progress Across the Generations," Paper presented at the Annual Meeting of the American Economic Association, Chicago, Illinois, January.

SMITH, JAMES P. AND BARRY EDMONSTON, EDS.

1997 The New Americans: Economic, Demographic, and Fiscal Effects of Immigration. Washington, D.C.: National Academy Press.

1998 The Immigration Debate: Studies on the Economic, Demographic, and Fiscal Effects of Immigration. Washington, D.C.: National Academy Press.

SMITH, ROBERT

1998 "Commentary," in Crossings: Mexican Immigration in Interdisciplinary Perspectives, edited by Marcelo Suárez-Orozco, 145-155. Cambridge, MA: Harvard University Press.

\section{UNITED STATES COMMISSION ON IMMIGRATION REFORM AND MEXICAN} MINISTRY OF FOREIGN RELATIONS

1997 Binational Study of Migration Between Mexico and the United States: Final Report. Washington, D.C. and Mexico City.

\section{UNITED STATES GOVERNMENT ACCOUNTING OFFICE}

1997 H-2A Agricultural Guestworker Program: Changes Could Improve Services to Empoyers and Better Protect Workers. Washington, D.C. (GAO/HEHS-98-20).

\section{WALDINGER, ROGER}

1997 "Social Capital or Social Closure?-Immigrant Networks in the Labor Market." Working Paper no. 6, Lewis Center for Regional Policy Studies, University of California, Los Angeles.

WARD, PETER M.

1998 Mexico City. Revised $2^{\text {nd }}$ edition. Chichester and New York: John Wiley.

\section{WARREN, ROBERT}

1997 Estimates of the Undocumented Immigrant Population Residing in the United States: October 1996. Washington, D.C.: U.S. Department of Justice, Immigration and Naturalization Service. 


\section{WARREN, ROBERT AND JEFFREY S. PASSEL}

1987 "A Count of the Uncountable: Estimates of Undocumented Aliens Counted in the 1980 United States Census,” Demography 24, no. 3: 375-393. 
${ }^{1}$ In a paper written more than a decade earlier, using data from his field interviews with Mexican migrants residing in California and Illinois in 1978, Cornelius (1981) documented the beginnings of several of these changes in the profile of Mexican migration to the United States, especially the growing importance of the permanent-settler component and the increased participation of women and children. Using INS apprehension data from the 1980s, Bean, Espenshade, White, and Dymowski (1990) also documented increasing proportions of women and children among undocumented immigrants along the Mexico-U.S. border.

${ }^{2}$ The authors note that because education levels in Mexico have been rising over time (albeit at a slower pace than those in the United States) we should expect more recent cohorts of Mexican migrants to have higher levels of education than earlier ones. If a more recent migration cohort has a smaller proportion of migrants with at least a high school education vis-à-vis an earlier cohort, then migration has become less selective with respect to education.

${ }^{3}$ Curiously, the same researchers, in an earlier review of findings from 32 Mexican sending communities, had attacked what they termed the "stereotype of Mexican migrants as males of working age" who were overwhelmingly sojourners in the United States (Durand and Massey, 1992: 19-25). They also discussed the importance of many of the same sources of discontinuity in Mexican migration patterns that were emphasized by Cornelius (1992). Similarly, in a recent critique of U.S. immigration policy since 1994, Massey (1998) calls attention to the expansion of social networks in response to North American economic integration, which puts U.S. jobs within easy reach of "a growing fraction of the Mexican population." He also argues that recent changes in U.S. immigration policy (especially stronger border enforcement) have lowered the odds of return migration to Mexico, by increasing the costs and risks of repeated illegal entry. 
${ }^{4}$ The 1980 and 1990 PUMS, as well as the 1979 ENEFNEU and 1992 ENADID, are used mostly for comparative purposes in this paper. These surveys are described in detail elsewhere (Bean, Corona, Tuirán, and Woodrow-Lafield 1998).

${ }^{5}$ This is done by re-weighting the foreign-born Mexican population by age and/or all laborers aged 12 and older by year of departure categories in the 1990 PUMS to reflect the percentages in the ENADID data.

${ }^{6}$ The authors would like to thank Manuel García y Griego for suggesting this method.

${ }^{7}$ Not controlling for changes in age and settlement patterns, however.

${ }^{8}$ Controlling for age composition in the U.S. data will tend to bias the measured educational attainment of more recent entry cohorts in a downward direction given Mexico's general rise in educational attainment.

${ }^{9}$ Interestingly, the more mobile (irregularly-employed, day-laborer) component of the flow appears to be growing more selective in terms of education than migrants who are more settled in the United States.

${ }^{10}$ This historic region sent 54.3 percent in $1924,47.7$ in $1957,38.7$ percent in 1977 , and 33.2 percent in 1984 (García y Griego 1989:54).

${ }^{11}$ This trend is further confirmed by comparing data gathered in Mexico from undocumented Mexican workers deported from the U.S. in 1975 (Bustamante 1984: 16-20) with data from Mexican workers employed in California in 1987-88 (Cornelius 1992). Using the seven states (all except Nayarit and Colima) for which data exist for 1975 and all Mexican migrants employed in the U.S. in 1987-88, we find a 15.5 percentage point drop in "historic-region" migrants, from 65.9 to 50.4 percent. The $1987-88$ proportion is much lower (33.1 percent) when we sum the available data for undocumented Mexican immigrants born in six states (excluding Nayarit, Colima, and San Luis Potosí). 
${ }^{12} \mathrm{We}$ do not use the USC-COLEF Household Survey for this analysis because there is no question that permits the regional breakdown used in Table 6 .

${ }^{13}$ Durand, Massey and Zenteno (2000) find that the proportion born in places with over 15,000 did not change at all from the 1970-74 to the 1990-93 migrant cohort, when using ENADID data alone.

${ }^{14}$ The reader should note that the USC-COLEF data is perfectly comparable to neither the UCSD data nor the Mexico data in Table 8 given that the USC-COLEF data concern where one "had migrated from" versus "place of birth."

${ }^{15}$ The conversions are accomplished by multiplying a given estimated parameter coefficient in Table 9 by $p(1-p)$, where $p$ is the sample mean of the dependent variable (intended future nation of residence).

${ }^{16}$ This figure was computed by the authors using the March 1997 Current Population Survey.

${ }^{17}$ The focus on Mexican migrants' relatively lower levels of human capital transcends legal status considerations, but the two concerns are closely related.

${ }^{18}$ Interestingly, there has been no similar clamor for expanding immigration of moderately skilled, manual crafts workers, despite recent survey evidence of a growing shortage of such skilled workers throughout southern California, limiting the growth of many small businesses, especially in the manufacturing sector (D. Lee 1998).

${ }^{19}$ A recent paper by Heer (2000) argues that cumulative causation may be becoming less important due to Latino immigrant labor market saturation in the United States. 


\section{IZA Discussion Papers}

No Author(s)

B. R. Chiswick

132

D. N. F. Bell

R. A. Hart

O. Hübler

W. Schwerdt

134 A. D. Kugler

G. Saint-Paul

135 A. Barrett

P. J. O'Connell

136 M. Bräuninger

M. Pannenberg

J.-St. Pischke

138 J. Zweimüller

R. Winter-Ebmer

R. A. Hart

Y. Ma

140

141 R. Hujer

M. Wellner

142 J. J. Dolado

F. Felgueroso

J. F. Jimeno

143 P. J. Luke

M. E. Schaffer

144 G. Saint-Paul

145 M.-S. Yun

146 T. K. Bauer

J. P. Haisken-DeNew
Titel

Area

Date

Are Immigrants Favorably Self-Selected? An 1

$3 / 00$

Economic Analysis

Hours and Wages in the Depression: British 7 Engineering, 1926-1938

Paid and Unpaid Overtime Working in Germany and 1 the UK

Hiring and Firing Costs, Adverse Selection and 3

$3 / 00$

Long-term Unemployment

Is There a Wage Premium for Returning Irish 1

$3 / 00$

Migrants?

Unemployment and Productivity Growth: An

$3 / 00$

Empirical Analysis within the Augmented Solow

Model

Continuous Training in Germany

$3 / 00$

Firm-specific Training: Consequences for Job

$3 / 00$

Mobility

Wages, Hours and Human Capital over the

$3 / 00$

Life Cycle

Education and Earnings Growth: Evidence from $11 \quad 2 / 5$

$4 / 00$

European Countries

The Effects of Public Sector Sponsored Training on Individual Employment Performance in East

6

$4 / 00$

Germany

Explaining Youth Labor Market Problems in Spain: 3

$4 / 00$ Crowding-Out, Institutions, or Technology Shifts?

Wage Determination in Russia: An Econometric 4

$4 / 00$ Investigation

Flexibility vs. Rigidity: Does Spain have the worst of 1 both Worlds?

$4 / 00$

Decomposition Analysis for a Binary Choice Model 7

Employer Learning and the Returns to Schooling 5 
Does the Recent Success of Some OECD

149 R. Lalive

J. C. van Ours

J. Zweimüller

J. DiNardo

K. F. Hallock

J.-St. Pischke

151 M. Ward

152 J. J. Dolado

F. Felgueroso

J. F. Jimeno

153 A. S. Kalwij

M. Gregory

154 M. Gerfin

M. Lechner

155

J. Hansen

156

C. Dustmann

F. Fabbri

157 P. Apps

R. Rees

A. Björklund

T. Eriksson

M. Jäntti

O. Raaum

E. Österbacka

159 P.- J. Jost

M. Kräkel

160

M. Lofstrom

161
V. Gimpelson
D. Treisman
G. Monusova

162 C. Dustmann

M. E. Rochina-

Barrachina
The Impact of Active Labor Market Programs and

Benefit Entitlement Rules on the Duration of Unemployment

Unions and the Labor Market for Managers

7

$5 / 00$

Gender, Salary and Promotion in the Academic

5

$5 / 00$

Profession

The Role of the Minimum Wage in the Welfare

3

$5 / 00$

State: An Appraisal

Overtime Hours in Great Britain over the Period 3

$5 / 00$

1975-1999: A Panel Data Analysis

Microeconometric Evaluation of the Active Labour Market Policy in Switzerland

$5 / 00$

The Duration of Immigrants' Unemployment Spells: $\quad 1 / 3$

Evidence from Sweden

$5 / 00$

Language Proficiency and Labour Market Per- 1

$5 / 00$

formance of Immigrants in the UK

Household Production, Full Consumption and $\quad 7$

$5 / 00$

the Costs of Children

Brother Correlations in Earnings in Denmark, 5

Finland, Norway and Sweden Compared to the United States

Preemptive Behavior in Sequential Tournaments

5

$5 / 00$

A Comparison of the Human Capital and Signaling Models: The Case of the Self-Employed and the Increase in the Schooling Premium in the 1980's

$6 / 00$

Public Employment and Redistributive Politics: 4

$6 / 00$

Evidence from Russia's Regions

Selection Correction in Panel Data Models: An 6 $6 / 00$ 
B. Nolan

Immigration into Ireland

168 G. S. Epstein

A. L. Hillman

169 R. Winkelmann

T. K. Bauer

K. F. Zimmermann

C. Dustmann

F. Windmeijer

172

D. Card M. Ward

179 E. Wasmer P. Weil

180 T. K. Bauer I. N. Gang 
Discretionary Measures of Active Labor Market

A. Zaidi

189 W. Arulampalam

G. Brunello
Is Unemployment Really Scarring? Effects of Unemployment Experiences on Wages

Racial and Economic Factors in Attitudes to Immigration

Joint Decisions on Household Membership and Human Capital Accumulation of Youths: The role of expected earnings and local markets

Absolute Risk Aversion and the Returns to Education

5

$8 / 00$

The Determination of Wages and the Gender

5

$8 / 00$ Wage Gap: A Survey

Regional Unemployment and Industrial

Restructuring in Poland

Overeducation, Undereducation, and the Theory of Career Mobility

5

$9 / 00$

Equilibrium Wage Arrears: A Theoretical and 4 Empirical Analysis of Institutional Lock-In

$8 / 00$

$8 / 00$

$8 / 00$

Options to Quit 
X. Gong 
213 X. Gong

A. van Soest

E. Villagomez

214 X. Gong

A. van Soest

215 J. Ermisch

M. Francesconi

216 F. Büchel

217 J. Hansen

R. Wahlberg

218 C. Dustmann

A. van Soest

219 F. Kramarz

T. Philippon

220 W. A. Cornelius

E. A. Marcelli
Family Structure and Female Labour Supply in

5

$11 / 00$ Mexico City

The Effect of Parents' Employment on Children's Educational Attainment

5

The Effects of Overeducation on Productivity in Germany - The Firms' Viewpoint

Occupational Gender Composition and

5

Parametric and Semiparametric Estimation in 1 Models with Misclassified Categorical Dependent Variables

The Impact of Differential Payroll Tax Subsidies on 5 Minimum Wage Employment

The Changing Profile of Mexican Migrants to the United States: New Evidence from California and 1

$12 / 00$ Mexico 